\title{
COMPARISON OF THE EFFECTS OF ACETYLATION AND PARAFFIN EMULSION IMPREGNATION IN PINUS CARIBEAE
}

\author{
Schardosin FZ ${ }^{1, *}$, Nisgoski $\mathrm{S}^{2}$, Cademartori $\mathrm{PHG}^{2}$, Morrone $\mathrm{SR}^{2} \&$ Muniz GIB ${ }^{2}$ \\ ${ }^{1}$ Rua Miguel Giometti, 789, Jardim São João Batista, Cep - 13566-210, São Carlos, São Paulo State, Brazil \\ ${ }^{2}$ Engineering and Forest Technology Department, Federal University of Paraná, Avenida Prefeito Lothario Meissner, 900 \\ Jardim Botânico, 80210170 Curitiba, Parana, Brazil \\ *f.zattschardosin@gmail.com
}

Submitted April 2019; accepted January 2020

\begin{abstract}
The use of wood as building material has some disadvantages, especially in relation to water and dimensional stability. Wood modification methods have been studied in the past decades, including active methods such as acetylation and passive methods such as paraffin impregnation. Acetylation is very effective in avoiding water exchange in wood, but its large scale application is costly and capital demanding. Impregnation with paraffin emulsion could be a simpler and cheaper substitute method. In this context, this study had the objective to compare wood modification results of these two different methods. Pinus caribeae lamellas were acetylated and impregnated with wax emulsion in two different particle sizes. The modified slats were tested for water absorption in submersion, where the apparent contact angle was measured for distillate water, the thermal stability was tested by thermogravimetric analysis, color parameter was evaluated and near infrared (NIR) and visible light spectra were collected and segregated by principal component analysis (PCA). The particle size influenced the penetration of wax into the wood. For particle size $9 \mu \mathrm{m}$, the water absorption was similar to untreated wood, and similar to acetylated wood, particle size $3.9 \mu \mathrm{m}$. The external wax cover on the slats retained contact angles similar to acetylated wood, and higher than in untreated wood. The wax content in the slat influenced the thermogravimetric behavior of the modified wood, similar to lower equilibrium moisture content in acetylated wood. All treatments resulted in color changes of the wood surface. The principal component analysis was effective in segregating the acetylated wood from other treatments, and the different wax content in treated slats resulted in segregation of both paraffin waximpregnated woods. Paraffin emulsion impregnation could be a substitute for acetylation when reduction in water absorption was required.
\end{abstract}

\section{INTRODUCTION}

Wood's constant water exchange with the environment results in changes in its dimensions leading to undesired deformations, especially in juvenile wood of fast growing plantation species such as Pinus caribeae (Bao et al. 2001, Kojima et al. 2009, Gonçalves et al. 2019). Wood modification methods have been tested in the past decades, mainly on sealing the wood from water exchange, through a chemical reaction of hydroxyl group substitution in wood components or filling the cell void space (Sandenberg et al. 2017).

In the acetylation process, wood is impregnated with acetic anhydride which reacts with the hydroxyl groups within the cell walls resulting in permanent substitution by hydrophobic acetyl groups, thus, the residual hydroxyl groups are drastically reduced ( $\mathrm{Gu}$ et al. 2015). After the process the wood stays in constant swollen condition, therefore the wood equilibrium moisture content is reduced, and the swell and shrinkage rates are significantly reduced (Larsson 1998, Gröndahl et al. 2003, Popescu et al. 2014, Rowel 2014, Mantanis 2017).

There are previous records of acetylation in the literature for P. taeda, P. palustris, P. sylvestris, $P$. echinata, $P$. radiata and $P$. nigra (Rowel 2005, Papadopoulos and Tountziarakis 2011, Becks et al. 2018). However there no records of acetylation for $P$. caribea.

The acetylation of wood results in changes of the wood coloration. The changes may occur differently at different temperatures and with different catalysts applied to the reaction ( $\mathrm{Li}$ et al. 2009). The color change process of acetylated wood continues after the reaction, when the wood is exposed to sun light and heat. These changes are related to the degradation of lignin and formation of carbonyl groups (Mitsui \& Tolvaj 2005, Mitsui 2010). 
The acetylation process is expensive and trials to bring the production of acetylated wood to commercial levels failed in USA (by Koppers Incoparated in 1961 and Eastman Chemical Company in 2014), Russia (in 1977) and Japan (by Daiken Incoparated in 1984), due to the costs and investment required for the process (Rowel 2014, Rowel \& Dickerson 2014). Currently, acetylated wood production is only found in the Netherlands by Accsys Technologies, where $P$. radiata and Alnus spp. are acetylated (Mantanis 2017).

Paraffin wax is an inexpensive byproduct of petroleum refining, which is primarily composed of normal alkanes with carbon numbers ranging from C18-50 (Wang et al. 2010)

With the intention to add hydrophobicity to wood, wax emulsions are used, especially in the wood panel industry (Neimsuwan et al. 2008). Literature shows examples of wax application in wood, resulting in increase of dimensional stability, reduction of water permeability and increase in resistance to biodegradation (Kurt et al. 2008, Scholz et al. 2009).

Besides the normal modifications wax impregnations are also used in archeological studies to preserve ancient wood artifacts (Unger et al. 2001). The most commonly used wax is the paraffin wax, derived from petroleum, although the use of other alternative sources such as bee wax, carnauba wax and montan wax is also possible (Lesar \& Humar 2011). The main advantage of paraffin wax is its low reactivity, due to the absence of functional groups (Wolfmeier et al. 2005).

The impregnation of the wood with wax emulsion does not result in anatomical changes of the wood (Wang et al. 2015). Li et al. (2015) observed that impregnation of wood with melted wax blocked the cell voids completely, resulting in wood dimensional stabilisation. The impregnation of Picea abies wood with montan, polyethylene and oxidised polyethylene does not cause any color changes, but resulted in increased surface hydrophobicity (Lesar et al. 2008). The impregnation of wood with wax emulsions also results in reduction of capilar absorption of water (Lesar et al. 2008, Wang et al. 2015).

Considering the effects of wood acetylation and paraffin emulsion impregnation, and their clear differences in complexity and process costs, this study aimed to compare the effects of acetylation and impregnation with paraffin emulsions in P. caribea wood, related to water absorption, contact angle kinetics, color variation, thermal kinetics and NIR spectroscopy.

\section{MATERIALS AND METHODS}

\section{Raw material}

Twenty one year old $P$. caribeae trees were randomly selected from a $2 \times 3 \mathrm{~m}$ spaced plantation forest, located in the municipality of Uberlândia, Minas Gerais State, Brazil, between $19^{\circ} 07^{\prime} \mathrm{S} 48^{\circ} 40^{\prime} \mathrm{W}$, at a height of $744 \mathrm{~m}$. The climate is defined as tropical savanna (Aw), according to Köppen classification. The trees were felled and logs were cut in diameters ranging from 180 to $230 \mathrm{~mm}$. Around 1000 defectless lamellas, measuring 80 $\times 5 \times 185 \mathrm{~mm}$ (width $\times$ thickness $\times$ length), were sawn from the logs and kiln-dried to $7 \%$ moisture content.

\section{Wood treatment procedures}

Pinus caribaea wood were treated under different conditions: acetylation and wax impregnations (Table 1). Wood acetylation was performed by vacuum-pressure method, followed by heating of the lamellas. One hundred lamellas were impregnated directly with acetic anhydride, without the addition of catalysts. The lamellas were tied into two bundles of 50 lamellas layers each. The bundles were then placed inside a pressure vessel and acetic anhydride was poured inside. The air inside the lamellas was removed by vacuum (-0.93 Bar for $0.5 \mathrm{~h}$, followed by 10 Bar for $1 \mathrm{~h}$ ). Following that, the acetic anhydride was poured out of the pressure vessel, and the excess reagent inside the wood was removed by vacuum (-0.93 Bar for $0.25 \mathrm{~h})$. The bundles were taken out of the pressure vessel and placed inside a pre-heated laboratory kiln for 5 hours at $120^{\circ} \mathrm{C}$. Finally, the lamellas were stacked, using $5 \mathrm{~mm}$ spacers, and kiln-dried at $105^{\circ} \mathrm{C}$ for $24 \mathrm{~h}$ to reach constant weight.

Wax impregnations were carried out with two types of wax emulsions in a vacuum/pressure system at 13 bar and $80{ }^{\circ} \mathrm{C}$. One paraffin wax emulsion was a commercial product, Humocer 100 , and the other was emulsified in the laboratory using 2.5\% macro paraffin (melting point between 333 and $336 \mathrm{~K}$ ) and $1.5 \%$ sodium stearate as emulsifier. Both wax emulsions were diluted to $4 \%$ concentration. The commercial 
Table 1 Process conditions adopted to acetylation and wax impregnation treatments of Pinus caribaea wood

\begin{tabular}{cccccc}
\hline \multirow{2}{*}{ Treatment } & Product & $\begin{array}{c}\text { Vacuum time } \\
(\mathrm{h})\end{array}$ & $\begin{array}{c}\text { Temperature } \\
\left({ }^{\circ} \mathrm{C}\right)\end{array}$ & $\begin{array}{c}\text { Pressure } \\
(\text { bar })\end{array}$ & $\begin{array}{c}\text { Pressure } \\
\text { time }(\mathrm{h})\end{array}$ \\
\hline Acetylation & Acetic anhydride & 0.5 & 120 & 10 & 1 \\
II & Commercial wax emulsion $4 \%$ & 0.5 & 80 & 10 & 1 \\
IC & Laboratory wax emulsion 4\% & 0.5 & 80 & 10 & 1 \\
\hline
\end{tabular}

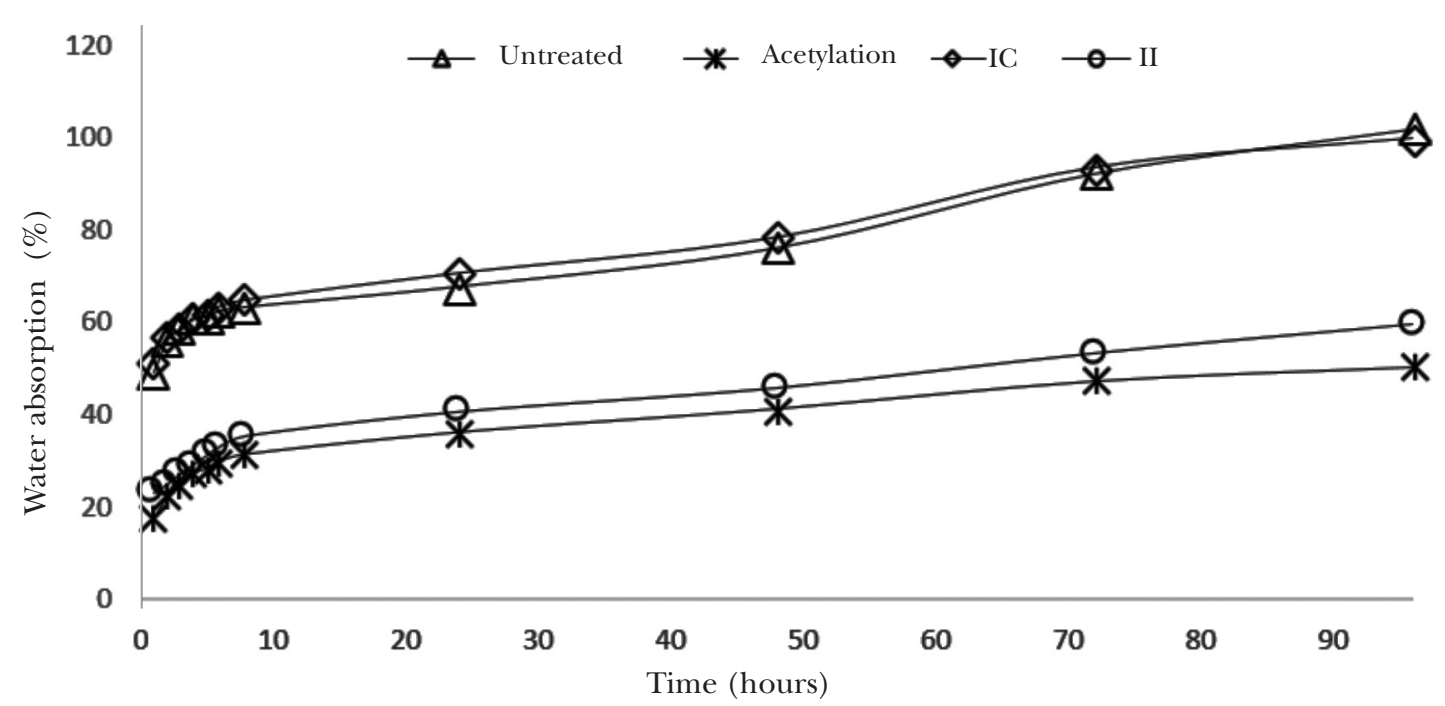

Figure 1 Kinetics of water absorption for untreated and treated Pinus caribaea wood (average)

wax emulsion presented particle size of around $3.9 \mu \mathrm{m}$, solids content of $3.2 \%$ and $\mathrm{pH} 8.81$, while the laboratory wax emulsion presented particle size of around $9 \mu \mathrm{m}$, solid content of $3.9 \%$ and $\mathrm{pH} 9.77$. After the impregnation step, treated wood was kiln-dried at $105{ }^{\circ} \mathrm{C}$ for $24 \mathrm{~h}$ to reach constant weight.

\section{Physical properties}

The load of wax emulsion impregnated in wood was quantified by the difference between the kiln-dried mass of the samples, before and after the treatment, as described by Lourençon et al. (2016).

Water absorption (WA) kinetics were determined by immersing kiln-dried wood samples in distilled water and controlling their masses as a function of time $(1,2,3,4,5,6,8,24$, 48,72 and $96 \mathrm{~h}$ ). For each treatment, 8 pieces of lamellas $(50 \times 5 \times 40 \mathrm{~mm})$ were used.

Changes on wettability of untreated and treated wood was measured with a goniometer, using sessile type contact angle technique. Apparent contact angle (WCA) was determined by deposition of three droplets of distilled water (surface tension of $72.80 \mathrm{~m} \mathrm{Nm}^{-1}$ ) with $5 \mu \mathrm{l}$ volume on wood surface. The WCA was monitored for 30 seconds in ten wood samples for each treatment, totaling to 50 lamellas samples and 150 measurements.

\section{Thermal evaluation}

One hundred grams of each treatment were milled in a Wiley knife mill, and the powder was sifted and the portion between 40 and 60 mesh was segregated. The thermogravimetric analysis (TGA) was performed without replicates in an equipment with argon atmosphere and gas flow of $100 \mathrm{~mL} \mathrm{~min}{ }^{-1}$. The wood powder samples were analysed at a temperature range of $25-600{ }^{\circ} \mathrm{C}$ and heating rate of $10^{\circ} \mathrm{C} \mathrm{min}{ }^{-1}$, where $10 \mathrm{mg}$ was used for each measurement.

\section{Color evaluation}

The colorimetric evaluation was performed using a spectrophotometer, with a spectral range of $400-750 \mathrm{~nm}$, D65 light source and 
$10^{\circ}$ observation angle (CIEL* $a^{*} b^{*}$ standard). Nine measurements of colorimetric parameters, lightness $\left(\mathrm{L}^{*}\right)$, red-green chromatic coordinate $\left(a^{*}\right)$ and blue-yellow chromatic coordinate $\left(b^{*}\right)$, were performed for each wood sample, totalling 225 measurements by treatment. Chroma $\left(\mathrm{C}^{*}\right)$, hue angle $\left(\mathrm{h}^{*}\right)$ and color variation $(\Delta \mathrm{E})$ were determined using equations I II, and III, respectively.

$$
\begin{aligned}
& \mathrm{C}=\left(\mathrm{a}^{* 2}+\mathrm{b}^{* 2}\right)^{1 / 2} \\
& \mathrm{~h}^{*}=\tan ^{-1}\left(\frac{\mathrm{b}^{*}}{\mathrm{a}^{*}}\right) \\
& \Delta \mathrm{E}=\sqrt{\Delta \mathrm{L}^{* 2}+\Delta \mathrm{a}^{* 2}+\Delta \mathrm{b}^{* 2}}
\end{aligned}
$$

\section{Statistics}

The results of the color measurements were submitted to a test of variance, and the means were compared according to Tukey test $(\alpha=0.05)$ using the Minitab software (version 18).

\section{Near infrared spectroscopy (NIR)}

Near infrared spectroscopy analyses were performed using a spectrophotometer, equipped with an integrating sphere and operating in reflectance mode. The equipment was set to operate for 64 scans with resolution of $4 \mathrm{~cm}^{-1}$ in a spectral range of $10,000-4,000 \mathrm{~cm}^{-1}$. Nine measurements were performed for each wood sample in a room with controlled temperature of $23 \pm 2{ }^{\circ} \mathrm{C}$ and relative humidity of $60 \%$.

\section{Principal component analysis (PCA)}

The Unscrambler X Chemometric Program (version 10.1) was used to analyse the data obtained by NIR and spectrophotometer. Exploratory modeling was derived by analysing the score and loading the graphs obtained by PCA to verify possible differences between treatments. First and second derivative of Savitzy-Golay (polynomial order $=2$, smoothing point $=21$ ) were applied to raw data. Spectral analysis was based on ASTM E1655-05 standard (ASTM 2000).

\section{RESULTS AND DISCUSSION}

\section{Physical properties}

Treatment II (commercial wax emulsion) resulted in $9.00 \pm 1.48 \%$ wax inside the wood, while treatment IC (lab wax emulsion) resulted in $6.30 \pm 0.61 \%$ wax retention. This lower amount of wax impregnated in IC treatment is due to the big particle size of the emulsion. Since they are

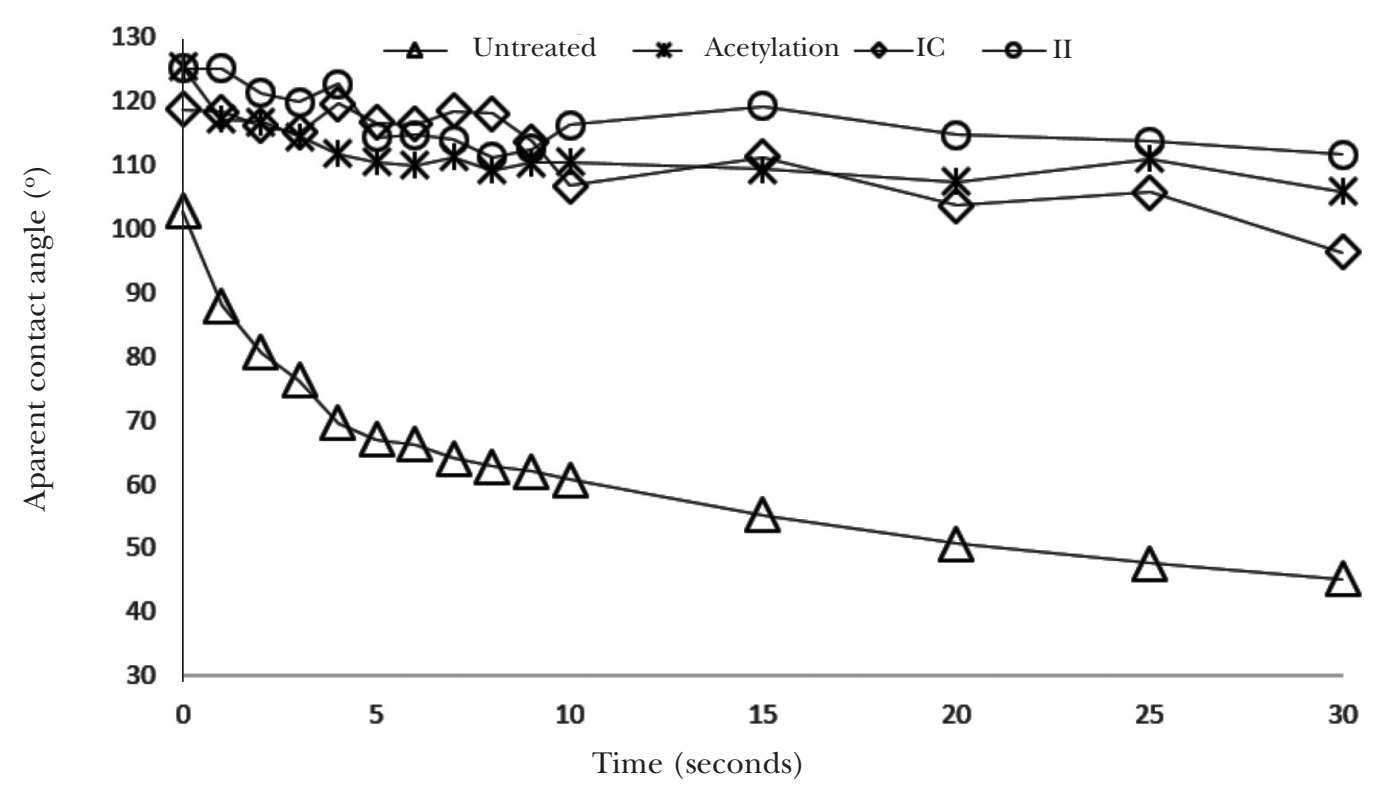

Figure 2 Time-resolved apparent water contact angle for untreated and treated Pinus caribaea wood (average) 

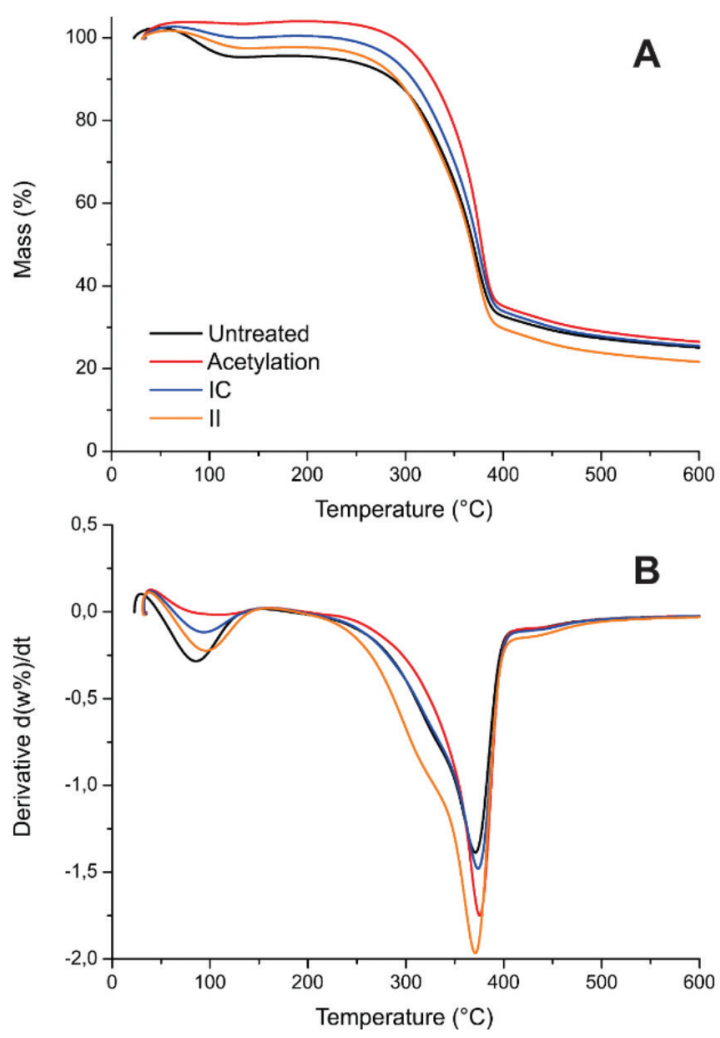

Figure 3 Termogravimetric analysis of modified and unmodified Pinus caribea

too big to pass through the cell pits, they remain in the more external cell layers, while the water present in the emulsion goes all the way to the middle of the wood (Lesar et al. 2008, Lesar \& Humar 2011). This suggested the use of wax emulsion for surface coating and protection against water penetration.

Kinetics of water absorption showed optimal conditions to decrease hygroscopicity of pinewood. The lowest water absorption was exhibited by acetylated wood, followed by treatment II.

In the first eight hours of immersion, treatments presented fast weight gain. The WA of acetylated wood and treatment II were 31.5 and $35.4 \%$, respectively. On the other hand, treatment IC presented a WA of $55 \%$, reaching close to WA of untreated wood $(63 \%)$. Clear evidences of the efficiency of each treatment were observed at 24 to $96 \mathrm{~h}$ of immersion. As expected, untreated wood was fully saturated by water, while acetylated wood and treatment II presented a maximum WA of 50-59\%. Treatment IC also presented full saturation of water, which confirmed its inefficiency to decrease wood hygroscopicity.
The result obtained for acetylated wood may be due to the substitution of free hydroxyl groups, for acetyl groups (esterification), into wood chemical structure. However, no chemical reactions were observed between wax molecules and wood components.

Untreated wood presented a hydrophilic surface with an intense decrease of WCA (approx.49\%) as a function of time. The WCA analysis confirmed WA behavior. The ability of wax emulsion to coat only the wood surface was observed by the higher droplet stability.

All impregnations with wax emulsions resulted in a hydrophobic wood surface with WCA in a range of $118-139^{\circ}$. Acetylated wood presented initial WCA of $117^{\circ}$. Thus, both acetylation and wax emulsion treatments were able to convert hydrophilic wood surface into a hydrophobic one. Nevertheless, WCA slightly reduced as a function of time (10-18\%), showing that hydrophobic effect only partly controls the water resistance of wax-treated wood and acetylated wood (Rowell 2005).

\section{Thermogravimetric analysis (TGA)}

The acetylated wood had a more stable behavior when exposed to temperatures in the range of 25 to $300{ }^{\circ} \mathrm{C}$. The influence is mainly related to the lower availability for water molecules inside the cell walls, due to substitutions of hydroxils (Gröndahl et al. 2003). The paraffin coating inside the cell walls of the wax impregnated wood seemed to hinder water exchange in the initial phase of the heating. However, when the temperature surpassed $250{ }^{\circ} \mathrm{C}$, treatment II started losing mass, especially due to the degradation of its higher paraffin content. The effect is similar to the one observed by Wang et al. (2015) when wax impregnated wood was heat treated.

\section{Color and NIR evaluation by PCA}

Figure 4 presents a visual aspect of the untreated and treated wood samples. Clear color differences could be attributed to the different types of impregnations performed in wood.

Colorimetric parameters $\mathrm{L} * a^{*}, b^{*}, C^{*}$ and $h$ (Table 2) of P. caribeae wood significantly varied between acetylation and wax emulsion impregnation. The $\mathrm{L} *$ of treated wood decreased to a range of 60.41 and 73.02 , especially in acetylated wood with about $22 \%$ reduction. This 
decrease resulted in wood darkening and was driven by a great increase of color difference $(\Delta \mathrm{E})$. Changes in colorimetric parameters of wax-treated wood were statistically significant, but was not clearly represented on wood surface visual aspects (Figure 4).

According to Mattos et al. (2015) decrease of colorimetric parameters can be associated to chemical modifications caused by temperature or thermochemical reactions as lignin auto condensation and condensation reactions involved in treatments, such as thermal and chemical modifications. In this study, the general decrease of colorimetric parameters, especially

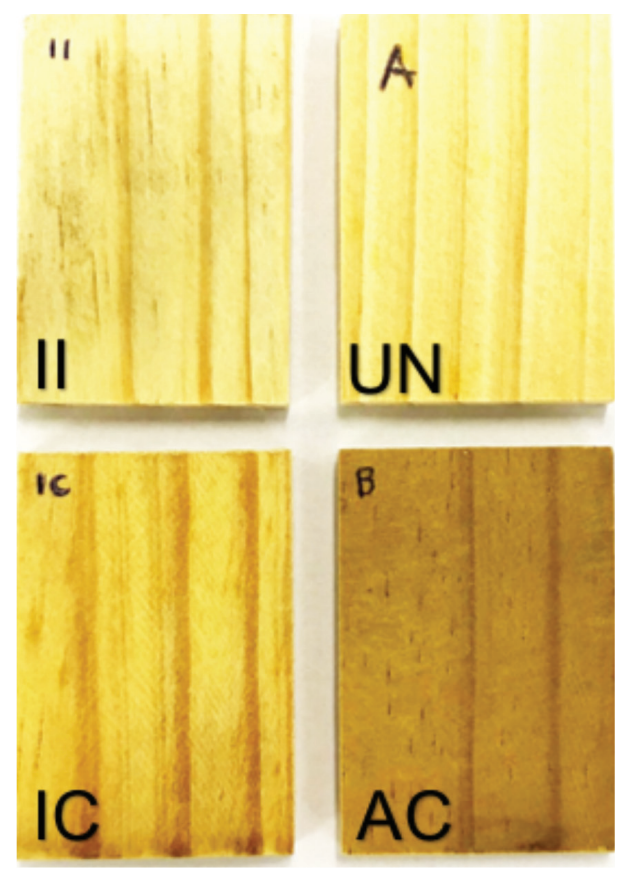

Figure 4 Aspect of the modified and unmodified Pinus caribeae samples (II = commercial emulsion, $\mathrm{IC}=\mathrm{lab}$ emulsion, $\mathrm{AC}=$ acetylated and $\mathrm{UN}=$ untreated) for acetylated wood, was driven by chemical reactions, since no high temperatures were used in acetylation or wax emulsion impregnation.

The reflectance curve in visible range (Figure 5A) showed that untreated wood had higher reflectance in all wavelengths, and acetylated wood the lowest reflectance. On the other hand, wood with wax impregnation was in the intermediate position, with some divergence between treatments: in all wavelengths of treatment II, and in the region of 600-740 nm in treatment IC, corresponding to yellow-red regions, confirmed by visual aspects (Figure 4).

Based on the score plot of PCA analysis (Figure 5B), it was verified that acetylating caused more visual changes in the analysed material, i.e. wood becoming brownish and forming isolated grouping. Untreated wood and wax impregnations presented similar distribution, however separated from each other. This was the result of alterations in reflection of visible light in function of the deposition of the wax films on cell walls surfaces, thus working like filters especially for red and green wavelength ranges.

Changes in wood color after acetylation process are variable and depend on the process, species and light irradiation, and can be related to structural changes of the extractives (Fodor \& Neméth 2017). Mitsui (2010) observed increase in $\mathrm{L}^{*}$ of acetylated spruce wood, decrease in $\mathrm{C}^{*}$ in regions 430 $500 \mathrm{~nm}$, and increase in $\mathrm{h}^{*}$, related to lignin degradation and production of carbonyl groups.

In this study, the region with more influence on treatment discrimination was $420-520 \mathrm{~nm}$ (Figure 5C). The same observed by Lengowski et al. (2018) in P. taeda, who related a negative effect on light reflection of thermally treated wood and low reflection rate of violet, blue and green light between $400-520 \mathrm{~nm}$.

Table 2 Color measurements of untreated and treated Pinus caribeae wood

\begin{tabular}{cccccc}
\hline Treatment & $\mathbf{L}^{*}$ & $\mathbf{a}^{*}$ & $\mathbf{b}^{*}$ & $\mathbf{C}^{*}$ & $\mathbf{h}^{*}$ \\
\hline Untreated & $77.77 \mathrm{a}$ & $7.12 \mathrm{ab}$ & $29.21 \mathrm{a}$ & $30.08 \mathrm{a}$ & $76.34 \mathrm{~b}$ \\
& $(1.6)$ & $(1.2)$ & $(1.4)$ & $(1.6)$ & $(2.0)$ \\
Acetylated & $60.41 \mathrm{c}$ & $7.75 \mathrm{a}$ & $27.06 \mathrm{~b}$ & $28.16 \mathrm{~b}$ & $73.99 \mathrm{c}$ \\
& $(4.2)$ & $(0.5)$ & $(1.4)$ & $(1.4)$ & $(1.4)$ \\
IC & $73.02 \mathrm{~b}$ & $6.72 \mathrm{~b}$ & $28.33 \mathrm{a}$ & $29.13 \mathrm{ab}$ & $76.72 \mathrm{~b}$ \\
& $(3.4)$ & $(1.2)$ & $(1.90)$ & $(2.1)$ & $(1.8)$ \\
II & $72.32 \mathrm{~b}$ & $5.92 \mathrm{c}$ & $28.11 \mathrm{ab}$ & $28.74 \mathrm{~b}$ & $78.16 \mathrm{a}$ \\
& $(4.0)$ & $(1.0)$ & $(1.8)$ & $(1.9)$ & $(1.7)$ \\
\hline
\end{tabular}

*Mean values followed by the same letter do not differ statistically by Tukey test at $95 \%$ probability 

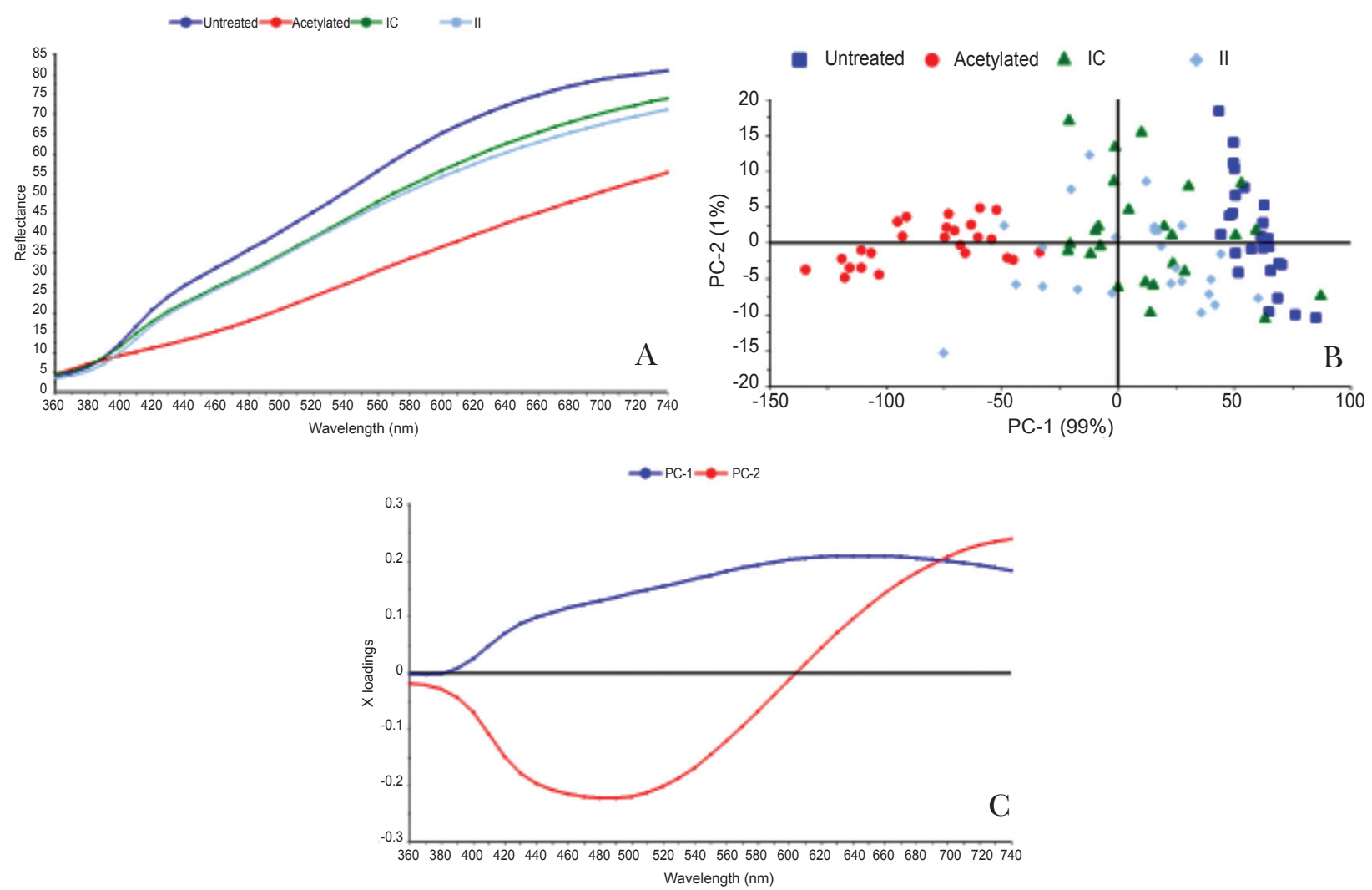

Figure 5 Visible color spectroscopy and principal component analysis (PCA) results for the modified wood of Pinus caribea

The NIR original data (Figure 6A) of $P$. caribeae wood, treated and untreated, showed similarity to lignocellulosic materials (Schwanninger et al. 2011). However, differences in some region was observed in function of applied treatment. Acetylated material presented less absorbance in all wavelengths, and the peaks at $5944 \mathrm{~cm}^{-1}$, $5811 \mathrm{~cm}^{-1}$ and $4428 \mathrm{~cm}^{-1}$ related to changes in cell wall components, principally groups of lignin. In samples with wax impregnations some divergence was observed. Treatment IC was similar to untreated wood, probably because wax impregnation was superficial without chemical changes. In the case of treatment II impregnation, more absorbance in NIR region was observed, and peaks at $5776 \mathrm{~cm}^{-1}$, $5666 \mathrm{~cm}^{-1}, 4320 \mathrm{~cm}^{-1}$ and $4252 \mathrm{~cm}^{-1}$, principally related to cellulose and hemicellulose bonds (Schwanninger et al. 2011). Corroborating literature commented that acetylating lignin is more reactive, after hemicelluloses and cellulose, as a result of reduction in equilibrium moisture content of the modified wood due to bulking and/or OH substitution (Popescu et al. 2014, Sadeghifar et al. 2014).
Most studies in literature used fouriertransform infrared spectroscopy (FTIR) to analyse the chemical modifications in wood after acetylating or impregnation with paraffin. In general, after acetylating peaks of hydroxyl absorption are largely reduced, equilibrium moisture content are reduced, level of acetylating increases and fiber saturation point decreases (Popescu et al. 2014, Rowell 2014, Gu et al. 2015). In FTIR spectra analysis, bands related to $\mathrm{C}=\mathrm{O}$ bonds of hemicellulose and C-O of lignin increases significantly after acetylating (Huang et al. 2018). This justifies the results obtained in this study with NIR spectra where acetylated samples were different from untreated and wax impregnated wood. Bands in NIR attribute to water content or bonds and are presented in loading graphs of PCA, with influence in grouping formation: wavenumbers at around 7073, 6974-6954, 5220-5150, $5051 \mathrm{~cm}^{-1}$ (Schwanninger et al. 2011). Also, wavenumbers for cell wall components, principally lignin and hemicelluloses, are present in grouping formation of treated and untreated materials. 

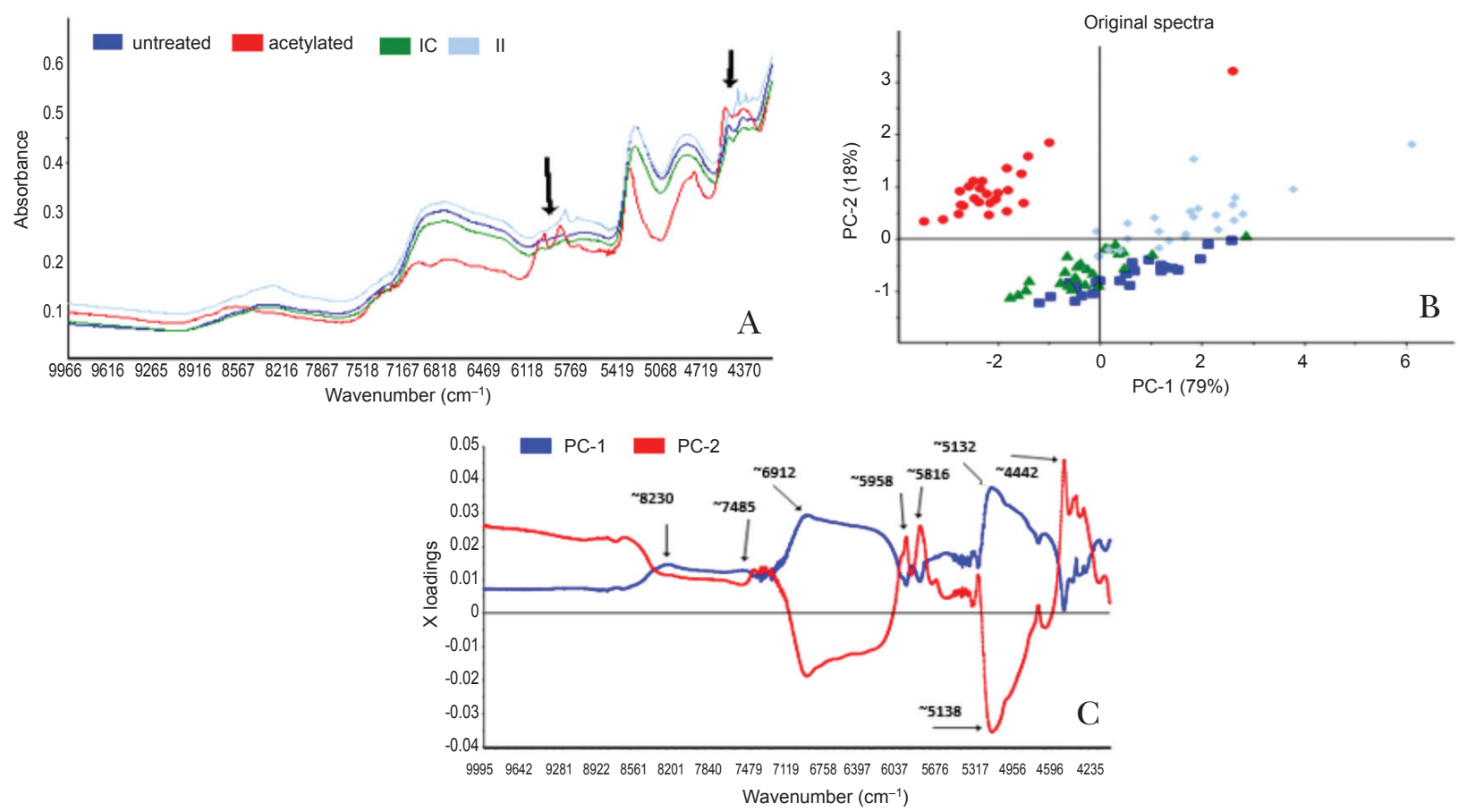

Figure 6 NIR spectroscopy and principal component analysis (PCA) results for the modified wood of Pinus caribea

\section{CONGLUSIONS}

Particle size of the emulsion influenced the penetration of wax into the wood. For particle size $9 \mu \mathrm{m}$, the water absorption was similar to untreated wood, and for $3.9 \mu \mathrm{m}$, similar to acetylated wood. The externally covered wax on the slats returned WCA after 5 s of $114-117^{\circ}$, similar to acetylated wood of $110^{\circ}$, and higher than untreated wood of $67^{\circ}$. The wax content of the slat influenced the thermogravimetric behavior of modified wood, resulting in increased mass loss after $250^{\circ} \mathrm{C}$ due to paraffin degradation. The lower equilibrium moisture content of acetylated wood, did not result in mass loss, in the range close to $100{ }^{\circ} \mathrm{C}$. All treatments resulted in color changes of the wood surface. The PCA analysis was effective in segregating the acetylated wood from other treatments, and the different wax content in treated slats resulted in segregation of wax impregnated woods. Impregnation with wax emulsion showed similar potential as acetylation sealing of wood surface against water, and in the case of impregnation with low particle size the water absorption reduced to similar levels. However, the acetylation treatment is not replaceable due to other benefits. It is recommended that further studies should focus on combining these two treatments to reduce the cost of the current acetylation process.

\section{REFERENCES}

Bao F, Jiang Z, Jiang X et al. 2001. Differences in wood properties between juvenile wood and mature wood in 10 species grown in China. Wood Science and Technology 35: 363-375. doi:10.1007/s002260100099.

Beck G, Thybring Ee, Thygesen LG \& Hill C. 2018. Characterization of moisture in acetylated and propionylated radiata pine using low-field nuclear magnetic resonance (LFNMR) relaxometry. Holzforschung 72: 225-233. doi:10.1515/hf-20170072.

Fodor F \& NÉmeth R. 2017. Testing the photostability of acetylated and boiled linseed oil-coated common hornbeam (Carpinus betulus L.) wood. Acta Silvatica et Lignaria Hungarica 13: 81-94. https://doi. org/10.1515/aslh-2017-0006.

Gonçalves JC, Vieira FS, Camargos JAA \& Zerbini NJ. 2009. Influência do sítio nas propriedades da madeira de Pinus caribeae var. hondurensis. Cerne 15: 251-255.

Gröndahl M, Teleman A \& Gatenholm P. 2003. Effect of acetylation on the material properties of glucuronoxylan form aspen wood. Carbohydrate Polymers 52: 359-366. doi: 52. 10.1016/S01448617(03)00014.

Gu X, Sun L, Liu G, You C, Cheng CKK \& Yao J. 2015. Chemical modification of poplar wood in gas and liquid-phase acetylation. Wood Research 60: 247-254.

Huang X, Kocaefe D, Kocaefe Y \& Pichette A. 2018. Combined effect of acetylation and heat treatment on the physical, mechanical and biological behavior of jack pine (Pinus banksiana) wood. European Journal Wood Products 76: 525-540. doi: 76. 10.1007/s00107017-1232-5. 
Kojima M, Yamamoto H, Okumura K et al. 2009. Effect of the lateral growth rate on wood properties in fast-growing hardwood species. Journal of Wood Science 55: 417. https://doi.org/10.1007/s10086-009-1057-x.

Kurt R, Krause A, Militz H \& Mai C. 2008. Hydroxymethylated resorcinol (HMR) priming agent for improved bondability of waxtreated wood. Holz Roh-Werkstoff 66: 333-338. https://doi.org/10.1007/s00107-0080265-1.

LARSSON BP. 1998. Acetylation of Solid Wood: Wood Properties and Process Developement. Department of Forest Products and Chemical Engineering 6, Chalmers University of Technology, Göteburg.

Lengowski EC, Muniz GIB, Klock U \& Nisgoski S. 2018. Potential use of nir and visible spectroscopy to analyze chemical properties of thermally treated wood. Maderas. Ciencia y Tecnología 20: 62-640. doi: http:// dx.doi.org/10.4067/S0718-221X2018005041001.

Lesar B \& Humar M. 2011. Use of wax emulsions for improvement of wood durability and sorption properties. European Journal of Wood and Wood Products 69: 231-238. https://doi.org/10.1007/s00107-0100425-y.

Lesar B, Zupancic M \& Humar M. 2008. Microscopic analysis of wood impregnated with aqueous montan wax emulsion. Les Wood 60: 320-326.

Li JZ, Furuno T, Zhou WR, Ren Q, Han XZ \& Zhao JP. 2009. Properties of acetylated wood prepared at low temperature in the presence of catalysts. Journal of Wood Chemistry and Technology 29: 241-250. doi: 10.1080/02773810903009499.

Li Y, Li X, Huang Q, Wu Y, Li X \& Chen Z. 2015. Impregation with microcrystaline wax to improve rosewood dimensional stability and surface hardness. BioResources 10: 5994-6000. doi: 10.1080/02773810903009499.

Lourençon TV, Mattos BD, Cademartori PHG \& Magalhães WLE. 2016. Bio-oil from a fast pyrolysis pilot plant as antifungal and hydrophobic agent for wood preservation. Journal of Analytical and Applied Pyrolysis 122: $1-6$.

Mantanis GI. 2017. Chemical modification of wood by acetylation or furfurylation: a review of the present scaled-up technologies wood chemical modification. BioResources 12: 4478-4489. doi: 10.15376/biores.12.2.4478-4489.

Mattos BD, Lourençon TV, Serrano L, Labidi J \& Gatto DA. 2015. Chemical modification of fast-growing eucalyptus wood. Wood Science and Technology 49: 273-288. doi: https://doi.org/10.1007/s00226-0140690-8.

Mrtsui K \& Tolvaj L. 2005. Color changes in acetylated wood by the combined treatment of light and heat. Holz Roh-Werkstoff 63: 392-393. doi:10.1007/s00107-0050022-7.

Mrtsui K. 2010. Acetylation of wood causes photo bleaching. Journal of Photochemistry and Photobiology B: Biology 101: 210-214. doi: https://doi.org/10.1016/j. jphotobiol.2010.07.005.
NeImsuwan T, Wang S \& Via BK. 2008. Effect of processing parameters, resin, and wax loading on water vapor sorption of wood strands. Wood Fiber and Science 40: 495-504.

Papadopoulos AN \& Toutziarakis P. 2011. The effect of acetylation on the Janka hardness of pine wood. European Journal of Wood and Wood Products 69: 499-500. doi: https://doi.org/10.1007/s00107-0100484-0.

Popescu CM, Hill CAS, Gurling S, Ormondroyd G \& Xie Y. 2014. The water vapour sorption behaviour of acetylated birch wood: how acetylation affects the sorption isotherm and accessible hydroxyl content. Journal of Material Science 49: 2362-2371. doi:10.1007/s10853-013-7937-x.

Rowell RM \& Dickerson JP. 2014. Acetylation of Wood. Pp 301-327 in Schultz TP et al. (eds) Deterioration and Protection of Sustainable Biomaterials: ACS Symposium Series 1158. American Chemical Society, Washington DC. doi:10.1021/bk-2014-1158.ch018.

Rowell RM. 2005. Handbook of Wood Chemistry and Wood Composites. First Edition. CRC Press, New York.

RowELL RM. 2014. Acetylation of wood - a review. International Journal of Lignocellulosic Products 1: 1-27.

Sadeghifar H, Dickerson JP \& Argyropoulos DS. 2014 Quantitative 31P NMR analysis of solid wood offers an insight into the acetylation of its components. Carbohydrate Polymers 113: 552-560. doi: https:/ / doi. org/10.1016/j.carbpol.2014.07.046.

SANdBerg D, Kutnar A \& Mantanis G. 2017. Wood modification technologies - a review. iForest - Biogeosciences and Forestry 10: 895-908.

Scholz G, Krause A \& Militz H. 2009. Capillary water uptake and mechanical properties of wax soaked Scots Pine. Pp 209-212 in Englund F et al. (eds) Proceedings of the Fourth European Conference on Wood Modification. 27-29 April 2009, Stockholm.

Schwanninger M, Rodrigues JC \& Fackler K. 2011. A review of band assignments in near infrared spectra of wood and wood components. Journal of Near Infrared Spectroscopy 19: 287-308. doi: https://doi. org/10.1255/jnirs.955.

Unger A, Schniewind AP \& Unger W. 2001. Conservation of Wood Artifacts. Natural Science and Archeology. Springer, Berlin.

Wang J, Severtson S \& Stein A. 2010. Significant and concurrent enhancement of stiffness, strength, and toughness for paraffin wax through organoclay addition. Advanced Materials 18: 1585-1588. doi: https://doi.org/10.1002/adma.200502615

WANG W, Zhu Y, CaOJ \& GUO X. 2015. Thermal modification of southern pine combined with wax emulsion preimpregnation: effect on hydrophobicity and dimensional stability. Holzforschung 69: 405-413. doi: 10.1515/hf-2014-0106.

Wolfmeier U, Schimidt H, Heinrichs Fi et al. 2005. Waxes. Wiley-VCH, Weinheim. 